doubled. The education estimates, Mr. Amory added, would be $£ 26.5$ million higher next year.

In a written answer to a question in the House of Commons on the same day, Mr. Amory said that most universities are apperently dissatisfied in varying degrees with the grants allocated to them by the University Grants Committee, especially for the first two yesrs of the quinquennium. The quinquennium settlement provides, however, for grants 8 per cent higher in the current academic year than in 1956-57, rising by a further 30 per cent over the next four years. To these will be added supplementary grants in respect of the cost of salary awards effective from last August, making the total grant 20 per cent higher in 1957-58 than in 1956-57.

It is proposed that the University College of Sussex should be built at Brighton, where the Corporation has offered a site of about 150 acres at Stanmer Park on the Lewes Rosd. Negotiations between the University Grants Committee and a committee representing the five local education authorities of Sussex and their education officers are at present in progress.

\section{Nuclear Reactor Safety}

The Parliamentary Secretary to the Minister of Power, Sir Ian Horobin, in a written reply in the House of Commons on February 10, said that the Government intended to introduce legislation to ensure, by a system of licensing and inspection, that nuclear reactors on land were effectively subject to control in the interests of public safety. Owners of such reactors would, like the Atomic Energy Authority, be required to prevent damage to property or personal injury from radioactive contamination and would be liable to pay compensation for such damage even from an unavoidable accident, except to the extent to which there was contributory negligence on the claimant's part. It was proposed to limit compensation in respect to any one incident to $£ 5$ million for each installation, and the insurance market was prepared to provide the necessary cover. The lisbility of the Atomic Energy Authority would not be affected, but problems of reactors in ships, submarines and aircraft required further study with regard particularly to the international aspects.

\section{Technical Co-operation in Africa South of the Sahara}

IN a written answer in the House of Commons on February 5, Mr. Ian Harvey, replying for the Secretary of State for Foreign Affairs, said that the Government and other members of the Comnaission for Technical Co-operation in Africa South of the Sahara have agreed to set up a Foundation for Mutual Assistance in Africa South of the Sahara. The Foundation is designed to facilitate and encourage the provision of technical assistance for that region and would be inaugurated at Accra at the end of February. The House would be asked to epprove provisions for a United Kingdom contribution of technical assistance through the Foundation, which would be under the general direction of the Commission with a combined secretariat.

\section{Land for Service Requirements}

ThE Land Powers (Defence) Bill, which is the first major Bill to implement the Grovernment pledges in the debate on the Franks report, seeks to terminate Defence Regulations relating to land and to make permanent provision for the much more limited powers required for defence purposes in time of perce. Sperking in the House of Commons on
February 10 on the second reading of the Bill, Mr. G. de Freitas said that in England, War Office hold. ings amounted to 1.47 per cent of the land; in Wales, 1.07 per cent; and in Scotland, 0.24 per cent. Asking for more information on the Govern. ment's policy on land for Service training, he stressed the need for knowledge of total Service requirements if supplementary requests were to be handled intelligently. The tendency should be for leas and leas land to be required by the Services but, after referring to the co-operation during the past year with the Nature Conservancy, of the War Office at Braunton Burrows and of the Royal Air Force at St. Kilda, as outstanding examples of the possibility of meeting the requirements of the Services side by side with those of scientific research, Mr. de Freitas pointed out that there were examples to the contrary. While accepting the general principle of the Bill, it was essential to see that the safeguards offered to the public were effective and that the objections of local authorities, the National Parks Commisaion and other bodies could be thoroughly examined. In his reply on the debate, the Attorney-General, Sir Reginald Manningham-Buller, said that the power to make representations to the Manoeuvres Commission, which was thereupon required to hold at least one public inquiry, was likely to be a much more effective way of protecting the amenity, ornithological and other interests in the land in an area covered by an Order in Council.

\section{New Roads}

REPLYING on a debate in the House of Lords on February 13 on the acquisition of land for roads, the Minister without Portfolio, Lord Maneroft, while agreeing that the announced programme of expenditure on roads of $£ 240$ million for the period 1958-62 was not big enough, claimed that it was commensurate with our resources of finance and man-power. Forty large projects on the Great North Road would be authorized by the end of the financial year and work on many was already in progress. Work on the Leicester by-pass, to cost nearly $£ 4$ million, was due to finish by the end of 1959. The Kingsferry Bridge in the Isle of Sheppey would cost more then fl million, the northern approach to the Blackwall Tunnel nearly $£ 2$ million, the Birmingham Ring Road, the first stage of which should be finished this year, about $£ 15$ million, and work would start in March on a section of the London-Yorkshire motorway, which would be 53 miles long, take 19 months to complete and cost $£ 15$ million. The Ross Spur, to start on March 9, would take two and a half years. Much detailed work was involved in the preparation needed for the acquisition of land for road schemes, and the Government was trying to accelerate this work. He hoped in future it would be possible to provide local authorities with a programme approved in principle for three or four years ahead, which would enable them to work out detrils of the schemes and sequire property in time for the Minister to authorize the grant in the year in which he originally expected to make financial provision. After stressing the importance of flexibility, Lord Mancroft said that the Minister of Transport and Civil Aviation had set up a special planning section which was prepering a twenty- to thirty-year master plan for roads.

\section{The Physics of Fluids}

The Physics of Fluids (1, No. 1 (January-February, 1958). Pp. ii +72. Published bi-monthly. Annual 